\title{
Seedling growth rate of 3 subspecies of big sagebrush
}

\author{
GORDON D. BOOTH, BRUCE L. WELCH, AND TRACY L.C. JACOBSON
}

\section{Abstract}

Differences in growth rate among 3 subspecies of big sagebrush (basin big sagebrush, mountain big sagebrush, and Wyoming big sagebrush) for mature plants have been reported by a number of workers. Little has been reported on comparisons of seedling growth rate among these 3 subspecies. Results of this study indicated that (1) over an extended period and in a non-water-limiting environment, the rate of seedling growth in Wyoming big sagebrush approached zero and was less than that of seedlings of basin and mountain big sagebrush; (2) basin and mountain big sagebrush continued to have nonnegligible growth rates even at the end of the study; and (3) Wyoming big sagebrush reached its point of maximum growth rate approximately 2 weeks earlier than did the other 2 subspecies. It appears that Wyoming big sagebrush has evolved, placing 2 important growth characteristics under genetic control: (1) the maximum growth rate is attained earlier (when more water is available to sustain such growth) than in the other 2 subspecies, possibly enhancing its ability to survive on xeric sites during the early stages of growth; and (2) top growth produces smaller aboveground parts, enhancing survival after the early stages.

\section{Key Words: Artemisia tridentata, water potential}

Differences in growth rate among 3 subspecies of big sagebrush (Artemisia tridentata ssp. tridentata-basin big sagebrush; $A$.t. ssp. vaseyana-mountain big sagebrush; $A$.t. ssp. wyomingensis-Wyoming big sagebrush) have been reported by a number of workers (McArthur and Welch 1982, Barker and McKell 1983, Barker et al. 1983, Welch and McArthur 1986). These studies were conducted using mature plants either growing in uniform gardens or in wildland situations. Little has been reported on comparing seedling growth rate among these 3 subspecies. Harniss and McDonough (1975), reported no seedling growth differences among the 3 subspecies when grown for 10 weeks under controlled-temperature regimens. This was in contrast with the results in mature plants.

The smaller Wyoming big sagebrush grows in drier habitats than the other subspecies (West et al. 1978, Barker and McKell 1983, Winward 1983).

\footnotetext{
Authors are project leader, principal research plant physiologist, and research associate, Intermountain Research Station, Forest Service, U.S. Department of Agriculture, Ogden, Utah 84401.

The use of trade or firm names in this paper is for reader information and does not imply endorsement by the U.S. Department of Agriculture of any product or service. Manuscript accepted 31 January 1990.
}

Evolutionary pressures in a drier habitat would tend to select for big sagebrush subspecies that either conserve water or utilize water early in the season before it becomes a limiting factor in survival. Water could be conserved by limiting aboveground growth in favor of root development. This is in agreement with data generated from studies of mature big sagebrush plants (Barker et al. 1983, Welch and McArthur 1986). However, this appeared not to be the case with seedlings (Harniss and McDonough 1975). Plants that quickly reach the time of most rapid growth (i.e., the highest growth rate) earlier in the year would have more water available at this critical point in their development.

We conducted this study to determine whether (1) over an extended period and in a non-water-limiting environment, the seedling growth rate in Wyoming big sagebrush is less than that of basin and mountain big sagebrush, (2) whether growth of all 3 subspecies approach zero at the end of 24 weeks (approximately 1 growing season), and (3) whether all 3 subspecies reach their periods of most rapid growth at the same time.

\section{Materials and Methods}

This study was conducted in a greenhouse. Plant material consisted of seed collected from 14 big sagebrush sites. The plant material collected from a single site is referred to in this paper as an accession. Basin big sagebrush was represented by 5 accessions, mountain big sagebrush by 5 , and Wyoming big sagebrush by 4 . Table 1 lists the acquisition sites of the 14 accessions. In all statistical analyses, the accessions of a given subspecies were treated as if they constituted a random sample from that subspecies.

The growth medium was prepared by dry-mixing 4 parts of screened ( 6 by $6 \mathrm{~mm}$ ) peat moss, 3 parts of expanded horticultural vermiculite, 3 parts of a dry fine sandy loam soil, and 2 parts number 3 silica sandblasting grit. Added to each $0.9 \mathrm{~m}^{3}$ of mixture was a fertilizer supplement consisting of $600 \mathrm{~g}$ of dolomite limestone, $600 \mathrm{~g}$ of agricultural limestone (rock dust), $340 \mathrm{~g}$ of agricultural gypsum, $110 \mathrm{~g}$ of calcium nitrate, $110 \mathrm{~g}$ of osmocote, $90 \mathrm{~g}$ of triphosphate, $15 \mathrm{~g}$ of frittered trace elements, and $5 \mathrm{~g}$ of sesquestrene iron-138. The growing medium was mixed in a concrete mixer. Enough water was added during the mixing so the medium would remain in a ball after being squeezed by hand. After mixing, the medium was heated to $76.7^{\circ} \mathrm{C}$ for 30 minutes with aerated steam. This treatment eliminates most soil-borne plant pathogens 
Table 1. Acquialtion dites for seed collections of 14 accesions of Artemisia tridenterta.

\begin{tabular}{|c|c|c|}
\hline Subspecies & Accessions & County and state \\
\hline$\overline{\text { Basin }}$ & $\begin{array}{l}\text { Gordon Creek } \\
\text { Clear Creek Canyon } \\
\text { Loa } \\
\text { Dove Creek } \\
\text { Kemmerer }\end{array}$ & $\begin{array}{l}\text { Carbon, Utah } \\
\text { Sevier, Utah } \\
\text { Wayne, Utah } \\
\text { Dolores, Colorado } \\
\text { Lincoln, Wyoming }\end{array}$ \\
\hline Mountain & $\begin{array}{l}\text { Summit } \\
\text { Hobble Creek } \\
\text { Pinto Canyon } \\
\text { Clear Creck Canyon } \\
\text { Sardine Canyon }\end{array}$ & $\begin{array}{l}\text { Iron, Utah } \\
\text { Utah, Utah } \\
\text { Washington, Utah } \\
\text { Sevier, Utah } \\
\text { Cache, Utah }\end{array}$ \\
\hline Wyoming & $\begin{array}{l}\text { Trough Springs } \\
\text { Kemmerer } \\
\text { Gordon Creek } \\
\text { Mayfield }\end{array}$ & $\begin{array}{l}\text { Humboldt, Nevada } \\
\text { Lincoln, Wyoming } \\
\text { Carbon, Utah } \\
\text { Sanpete, Utah }\end{array}$ \\
\hline
\end{tabular}

yet leaves most of the beneficial microorganisms (Nelson 1984). Next, the growing medium was placed in containers constructed of $9 \mathrm{~mm}$ plywood impregnated with copper-napthenate (Nelson 1984) and with drainage holes in the bottom. The container size was 45.7 by 45.7 by $125.0 \mathrm{~cm}$, resulting in a total volume of 0.261 $\mathrm{m}^{3}$-larger than the 3 -liter containers used in the Harniss and McDonough (1975) study. Thermocouple psychrometers, placed at 25.4 and $50.8 \mathrm{~cm}$ depth, were used to measure water potential on a weekly basis (Brown and Bartos 1982). Growth medium was placed within $1.0 \mathrm{~cm}$ of the top of the containers. Each container was sown 5 January 1983 with 5 seeds from a single accession, and the seeds were covered about $2 \mathrm{~mm}$ deep with number 3 silica sandblasting grit. Each accession was represented by 5 containers randomly placed in the greenhouse. Surface moisture was maintained by using a fogger until 3 or 4 seeds had germinated, after which no water was provided. After 20 days, all plants but 1 were removed from each container. The plant closest to the center of the container surface was kept. Greenhouse day temperature (12 hours) was $20^{\circ} \mathrm{C}$. Night temperature ( 12 hours) was $10^{\circ} \mathrm{C}$. Natural day length was extended by means of artificial light (Sylvania Grolux) to 12-hours.

During the 24 weeks, height was measured from the surface of the growing medium to the end of the terminal leaves. This measurement was recorded each week starting with the 7th week until the crowns of the plants were detached from the roots at the surface of the growing medium.

To describe and study growth patterns, we chose to fit a logistic function to the data. Because a plot of the data revealed an obvious increase in variance as the seedlings became larger, a logarithmic transformation was applied to the seedling heights before further

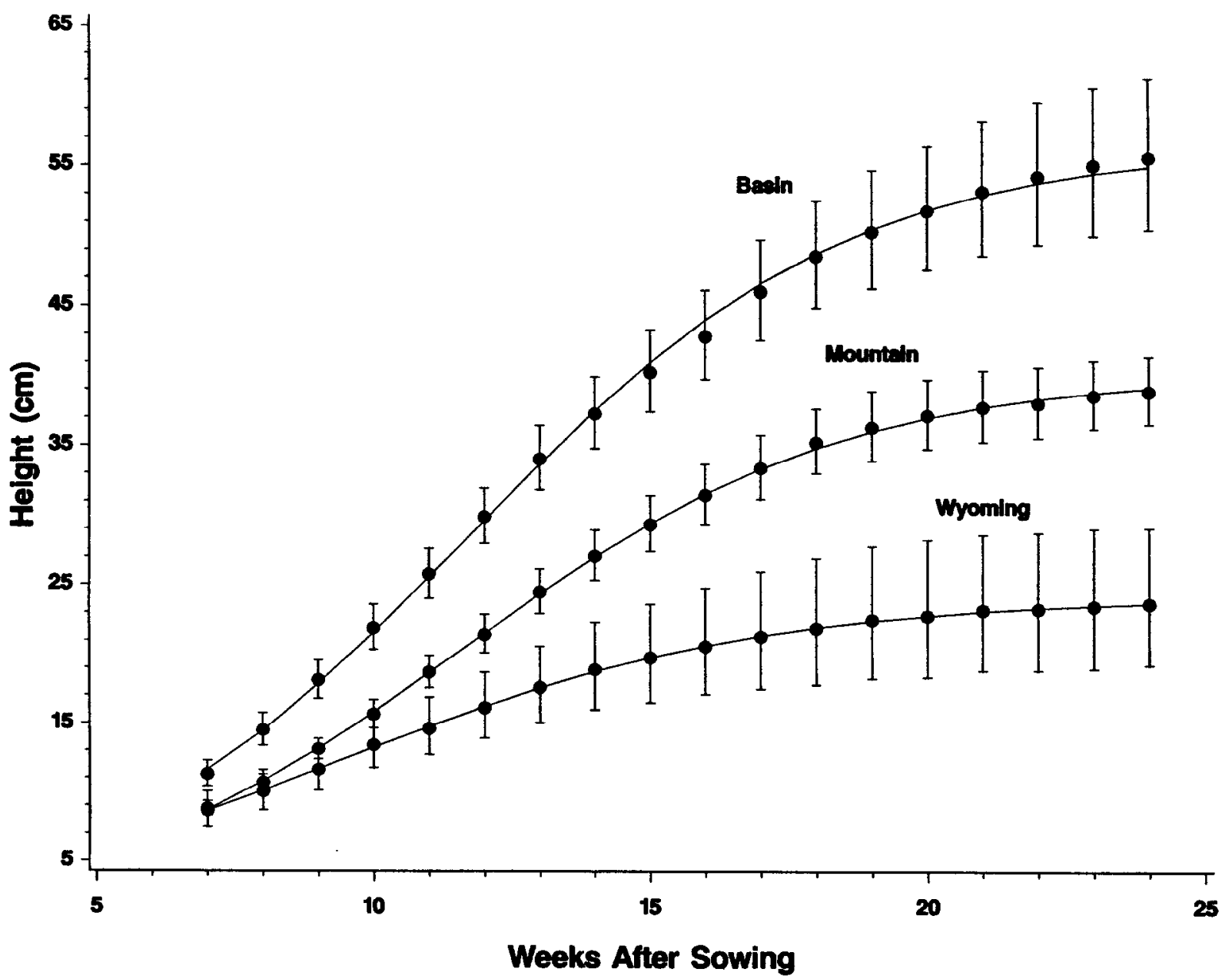

Fig. 1. The height of seedlings of 3 subspecies of big sagebrush (Artemisia tridentata ssp. tridentate-Basin big sagebrush; $A$.t. ssp. vaseyana-mountain big sagebrush; A.t. ssp. wyomingensis-Wyoming big sagebruah). The curves are the fitted logistic growth functions described in Table 2 . The means of all accessions are represented by solid dots, and the error bars (based on one-standard error of the mean) are plotted vertically. 
analysis. This necessitated fitting the following model to the transformed data in order to obtain a logistic relationship in the original scale:

$$
\ln (\text { Height })=\ln (\delta)-\ln (1+\alpha \exp (\beta \text { week })) .
$$

Because this model is nonlinear in the parameters $\alpha, \beta$, and $\delta$, a nonlinear least-squares fit was obtained. This method produces unbiased estimates of the parameters and asymptotic estimates of their variances. The estimates are then substituted into the logistic growth function:

$$
\text { Height }=\delta /(1+\alpha \exp (\beta \text { week }))
$$

Because the logistic function (1) reaches a maximum at its asymptote, $\delta$, this value-representing long-term height-is of interest. Furthermore, the first derivative of the logistic function (1), with respect to week, is a dynamic representation of growth rate. It will be referred to as the growth rate function and should not be confused with the growth function (1). The growth rate function is given by:

$$
\text { Rate }=\frac{(-\alpha \beta \delta \exp (\beta \text { week }))}{(1+\alpha \exp (\beta \text { week }))^{2}}
$$

The time, corresponding to the highest point on a plot of the growth rate function (2), represents the time of most rapid growth. It is important that sufficient growth resources, such as water, be available at this time. The time of most rapid growth is given by:

Time of Most Rapid Growth $=(1 / \beta) \ln (1 / \alpha)$.

(3)
Water potential was analyzed by computing a regression on weeks to determine whether a change occurred during the test period. The magnitude of the slope is a measure of the rate at which water potential is changing.

\section{Results}

Sagebrush plants were allowed to grow for 24 weeks. At the end of that period, the Wyoming big sagebrush had practically stopped growing, and the growth of both the mountain and basin big sagebrush had slowed considerably. The growing medium was starting to dry to the point where moisture could start to become limiting. Also, we did not want roots to grow in contact with the bottom of the containers.

The fitted logistic functions for seedling height of the 3 subspecies are plotted in Figure 1 along with the means and error bars of the data. The fit is good, as evidenced by the clean separation of the means in Figure 1 and by the small standard errors of the parameter estimates as presented in Table 2.

By week 7, the start of data collection, basin big sagebrush was taller than both the mountain and Wyoming subspecies (Fig. 1). This greater height continued throughout the study. Soon after week 7 , mountain big sagebrush began to produce taller seedlings than the Wyoming subspecies, but it did not achieve the height of the basin subspecies.

The growth rate functions (rates in $\mathrm{cm} /$ week), plotted against time (weeks after sowing), are presented in Figure 2. These functions are derived from the logistic functions that were fitted to the

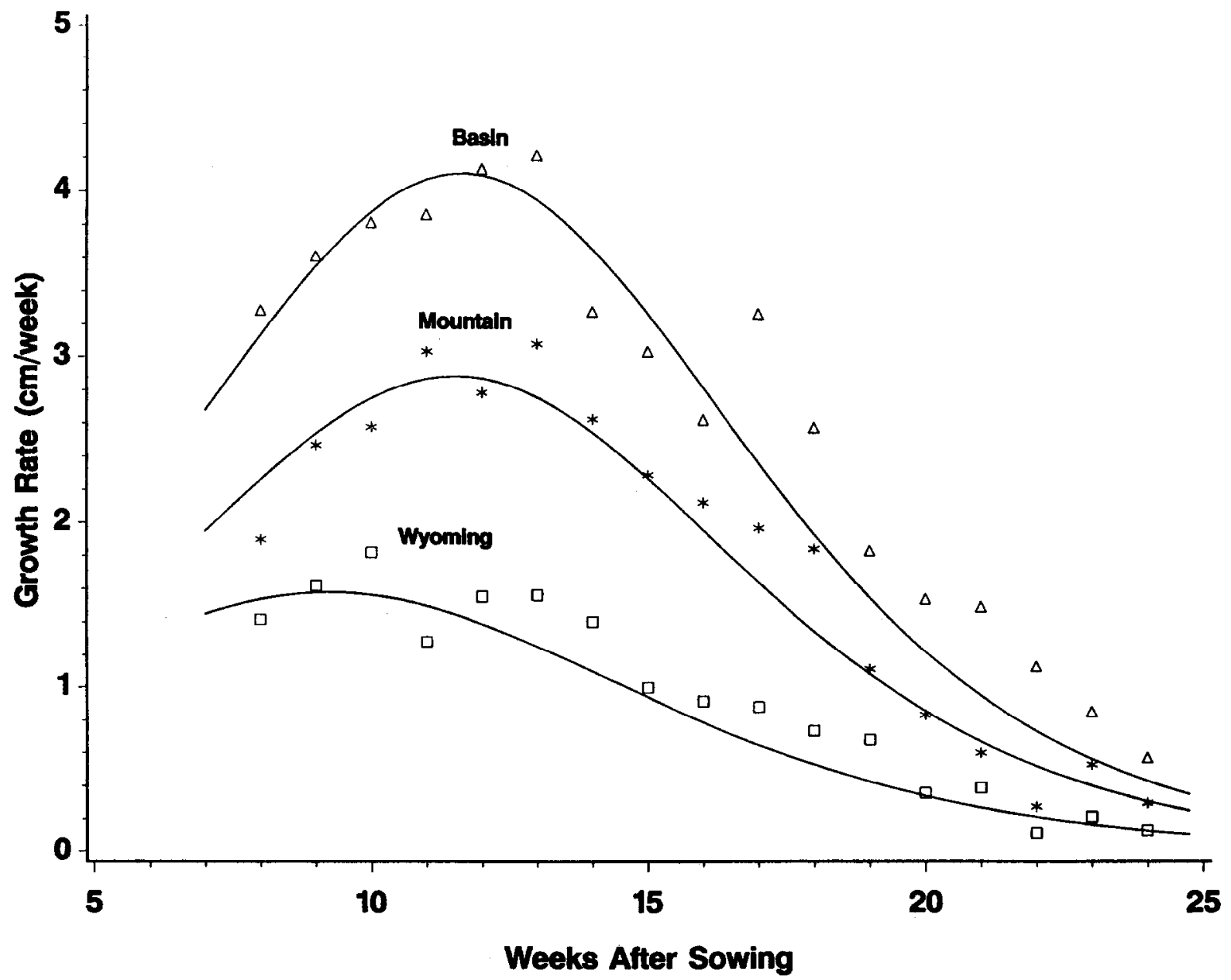

Fig. 2. The growth rate plotted against weeks since sowing for, seedlings of 3 subspecies of big sagebrush (Artemisia tridentata sap. tridentata-basin big sagebrush; A.t. ssp. vaseyana-mountain big sagebrush; A.t. ssp. wyomingensis-Wyoming big sagebrush). Each curve is the first derivative of the logistic function presented in Figure 1 , and the points represent successive first differences as estimates of the instantaneous slope. 
Table 2. Estimated logistic growth functions for 3 subspecies of big sagebrush (Artemisia tridentata) grown in a greenhouse environment for a period of 24 weeks after seeds were sown.

\begin{tabular}{lcccccc}
\hline \hline $\begin{array}{l}\text { Sub- } \\
\text { species }\end{array}$ & Estimate $^{\alpha}$ & SE' $^{\prime}$ & Estimate & SE & Estimate & SE \\
\hline Basin & 29.64 & 1.07 & -0.29 & 0.005 & 56.36 & 0.46 \\
Mountain & 27.08 & 0.52 & -0.29 & 0.002 & 40.20 & 0.17 \\
Wyoming & 11.28 & 0.25 & -0.26 & 0.003 & 24.11 & 0.09
\end{tabular}

Form of logistic function: $\delta /(1+\alpha \exp (\beta *$ Week $))$

${ }^{1}$ Asymptotic standard error as computed from nonlinear least-squares.

data. Basin and mountain big sagebrush are similar in growth pattern except that the basin subspecies grows at a uniformly higher rate (Fig. 2 and Table 3). Both achieved their maximum growth rates at about the same time, during the 12 th week. Basin big sagebrush attained a maximum growth rate of slightly more than $4 \mathrm{~cm}$ per week (at 11.9 weeks) while mountain big sagebrush reached a rate of only slightly more than $3 \mathrm{~cm}$ per week (at 11.4 weeks). On the other hand, Wyoming big sagebrush has a different growth pattern, reaching its fastest growth rate of only $1.7 \mathrm{~cm}$ per week approximately 2 weeks earlier ( 9.5 weeks) than the other 2 subspecies reached their fastest growth rates. Confidence intervals on the time required to reach the highest growth rate are presented in Table 3.

Table 3. Times of highest growth rates of 3 subspecies of big sagebrush (Artemisia tridentata) grown in a greenhouse for 24 weeks after seeds were sown.

\begin{tabular}{lcccc}
\hline \hline Subspecies & $\begin{array}{c}\text { Time of } \\
\text { maximum } \\
\text { growth } \\
\text { rate }^{1}\end{array}$ & $\begin{array}{c}\text { Lower } \\
\text { limit }^{2}\end{array}$ & $\begin{array}{c}\text { Upper } \\
\text { limit }\end{array}$ & $\begin{array}{c}\text { Maximum } \\
\text { rate }^{3}\end{array}$ \\
\hline Basin & weeks & weeks & weeks & cm/ week \\
Mountain & 11.87 & 11.74 & 12.00 & 4.02 \\
Wyoming & 11.40 & 11.32 & 11.48 & 3.01 \\
\hline
\end{tabular}

'The point of inflection of the logistic height function.

${ }^{2}$ Confidence intervals (95\%), obtained by error propagation, using the asymptotic variances and covariances from nonlinear least-squares.

${ }^{3}$ The height of the growth function at the point of inflection.

Growth rates for all 3 subspecies had decreased markedly by week 24 (Fig. 2). Moreover, by that time, the growth rate of the Wyoming subspecies was only about $0.2 \mathrm{~cm} /$ week.

Water potential measurements indicate none of the 3 subspecies was in a water-limiting environment (Table 4). Although there was a significant slope on the regression of water potential on time (when using the water potential measurement nearest the surface), the magnitude of the slope is small for each of the 3 subspecies. We concluded that, even under the most severe conditions encountered

Table 4. Water potential for 3 subspecies of big sagebrush (Artemisia tridentata) grown in a greenhouse environment for a period of 24 weeks after seeds were sown.

\begin{tabular}{|c|c|c|c|c|c|c|}
\hline \multirow{2}{*}{$\begin{array}{l}\text { Sub- } \\
\text { species }\end{array}$} & \multicolumn{3}{|c|}{ Top 1} & \multicolumn{3}{|c|}{ Bottom ${ }^{2}$} \\
\hline & Min & $\operatorname{Max}$ & Slope & Min & $\operatorname{Max}$ & Slope \\
\hline & & bars & & & bars & \\
\hline Basin & -3.1 & -9.5 & -0.17 & -1.4 & -7.1 & $\mathbf{N S}^{3}$ \\
\hline Mountain & -2.4 & -6.5 & -0.10 & -2.5 & -5.3 & NS \\
\hline Wyoming & -2.1 & -3.7 & -0.05 & -2.2 & -5.1 & NS \\
\hline
\end{tabular}

${ }_{1}$ Buried $25.4 \mathrm{~cm}$ below surface.

${ }^{2}$ Buried $50.8 \mathrm{~cm}$ below surface.

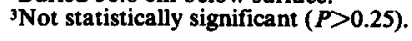

during the study, water was not sufficiently limited to retard seedling growth.

\section{Discussion}

Results presented in Figures 1 and 2 support our hypothesis that, over an extended period and in a non-water-limiting environment, the seedling growth rate of aboveground parts in Wyoming big sagebrush approaches zero and over the period is less than that of seedlings of basin and mountain big sagebrush. Water potential measurements remained in a non-water-limiting range over the entire study period (Table 4). Therefore, we conclude that water availability was not the factor that caused the Wyoming seedlings to stop growing. Perhaps the drier habitats-both in terms of lower precipitation and shallower soils-that Wyoming big sagebrush occupies in relation to the other subspecies exerted evolutionary pressure. This would cause Wyoming big sagebrush to evolve so that genetic control of growth would force it to reach its highest growth rate early and produce smaller aboveground parts.

Our study disagrees with the Harniss and McDonough (1975) report. They were unable in a 10-week study to differentiate the rate of growth of seedlings among the 3 subspecies. In our study, we detected obvious differences (Fig. 2) among the growth rate curves. Perhaps if their data had been subjected to the same logistic function analysis as ours, the results may have been in agreement.

In a companion study, Welch and Jacobson (1988) reported that for the first 10 days after germination the rate of root growth of Wyoming big sagebrush significantly exceeded that of basin and mountain big sagebrush. Part of this faster root growth was attributed to a faster germination rate for Wyoming big sagebrush. At 20 and 30 days, the rate of root growth of Wyoming and basin big sagebrush was not significantly different, but both significantly exceeded mountain big sagebrush. At $\mathbf{4 0}$ days, the rate of root growth of basin big sagebrush significantly exceeded that of Wyoming big sagebrush, which significantly exceeded that of mountain big sagebrush. At 174 days, basin and Wyoming big sagebrush root lengths were significantly longer than mountain big sagebrush, but were not different from each other. Thus, it appears that Wyoming big sagebrush has evolved to achieve maximum growth rate early in the growing season and to limit aboveground growth. These characteristics appear to be under genetic control because they remained consistent in a controlled environment. Limiting aboveground parts would allow the plant to assign energy to rapid and long root growth. These characteristics, and probably others, allow Wyoming big sagebrush to survive on xeric sites where basin and mountain big sagebrush cannot.

\section{Literature Cited}

Barker, J.R., and C.M. McKell. 1983. Habitat differences between basin and Wyoming big sagebrush in contiguous populations. J. Range Manage. $36: 450-454$.

Barker, J.R., C.M. McKell, and G.A. Van Epps. 1983. Shrub largeness: a case study of big sagebrush. p. 34-45. In: K.L. Johnson (ed), Proc. 1st Utah shrub ecology workshop, College of Natural Resources, Utah State Univ., Logan.

Brown, R.W., and D.L. Bartos. 1982. A calibration model for screen-caged Peltier thermocouple psychrometer. USDA Forest Serv. Res. Pap. INT-293.

Harniss, R.O., and W.T. McDonough. 1975. Seedling growth of three big sagebrush subspecies under controlled temperature regimens. J. Range Manage. 28:243-244.

McArthur, E.D., and B.L. Welch. 1982. Growth rate differences among big sagebrush (Artemisia tridentata) accessions and subspecies. J. Range Manage. 35:396-401.

Nelson, D.L. 1984. Toward producing disease-free container-grown native wildland plants. p. 32-38. In: P.M. Murphy (compiler), Proc. conference on challenge of producing native plants for the Intermountain area. USDA Forest Serv. Gen. Tech. Rep. INT-168. 
Welch, B.L., and T.L.C. Jacobson. 1988. Root growth of Artemisia tridentata. J. Range Manage. 41:332-334.

Welch, B.L., and E.D. McArthur. 1986. Growth rates of big sagebrush as influenced by accessions, sites, subspecies, and years. p. 342-346. In:E.D. McArthur and B.L. Welch (compilers), Proc. biology of Artemisia and Chrysothamnus. USDA Forest Serv. Gen. Tech. Rep. INT-200.
West, N.E., R.J. Trusch, K.H. Rea, and P.T. Tueller. 1978. Taxonomic determination, distribution, and ecological values of sagebrush within the pinyon-juniper woodlands of the Great Basin. J. Range Manage. 31:87-92.

Winward, A.H. 1983. Using sagebrush ecology in wildland management. p. 15-19. In: K.L. Johnson (ed.), Proc. 1st Utah shrub ecology workshop, College of Natural Resources, Utah State Univ., Logan. 